\title{
ERRATA
}

An error which inadvertently occurred in the Ghana Journal of Development Studies, Vol. 14, No. 1, 2017 is hereby corrected as follows:

\section{Assessing the Economic Efficiency of Maize Production in Northern Ghana}

\begin{tabular}{|c|c|c|}
\hline \multicolumn{3}{|c|}{ Errata } \\
\hline Section & Error & Correction \\
\hline \multirow[t]{2}{*}{$\begin{array}{l}\text { Authors' names } \\
\text { and institutional } \\
\text { addresses }\end{array}$} & $\begin{array}{l}\text { 1. Paul Kwame Nkegbe University } \\
\text { for Development Studies, Campus, } \\
\text { Ghana }\end{array}$ & $\begin{array}{l}\text { 1. Campus should be changed } \\
\text { to Tamale. }\end{array}$ \\
\hline & 2. Samuel A. Donkor & $\begin{array}{l}\text { 2. Donkor should be replaced } \\
\text { as Donkoh }\end{array}$ \\
\hline \multirow[t]{2}{*}{ Abstract } & $\begin{array}{l}\text { 1. First sentence of abstract: } \\
\text { This study used the stochastic frontier } \\
\text { model to examine the technical, } \\
\text { allocative and economic efficiency of } \\
\text { maize production in northern Ghana } \\
\text { using cross-sectional data for the } \\
\text { 2011/2012 cropping season }\end{array}$ & $\begin{array}{l}\text { 1. Instead, it should be } \\
\text { efficiencies. }\end{array}$ \\
\hline & $\begin{array}{l}\text { 2. Last sentence of abstract: } \\
\text { Fertilizer and labour are currently being } \\
\text { over-used and requires } 82.8 \% \text { and } 94.5 \% \\
\text { reductions respectively to reach their } \\
\text { allocatively efficient points. }\end{array}$ & 2. Replace with require \\
\hline Introduction & $\begin{array}{l}\text { Line 6, third sentence: } \\
\text { The introduction of output enhancing } \\
\text { technologies such as improved seeds } \\
\text { for cereals like maize, and use of } \\
\text { agrochemicals raised agriculture } \\
\text { productivity and transformed it into a } \\
\text { modern sector in Asia. }\end{array}$ & Replace with agricultural \\
\hline $\begin{array}{l}\text { Sub-section: } \\
\text { Maize Production } \\
\text { in Ghana (pp 124) }\end{array}$ & $\begin{array}{l}\text { First sentence: } \\
\text { The aim of Ghana's Medium Term } \\
\text { Agriculture Sector Investment Plan } \\
\text { (METASSIP) is to modernise agriculture } \\
\text { which }\end{array}$ & Insert METASSIP. \\
\hline
\end{tabular}

The Ghana Journal of Development Studies offers readers its most sincere apologies for the error. 